\title{
СОЦИАЛЬНО-ЭКОНОМИЧЕСКАЯ БЕЗОПАСНОСТЬ
}

\section{В. А. Черешнев, А. Н. Верзилин, Т. Г. Максимова, Е. В. Черешнева \\ СОЦИАЛЬНО-ЭКОНОМИЧЕСКИЙ МОНИТОРИНГ УГРОЗЫ РАСПРОСТРАНЕНИЯ ВИЧ/СПИД В РОССИЙСКОЙ ФЕДЕРАЦИИ}

УДК $311.312 ; 614.1$

\begin{abstract}
Предмет исследования - соииальные и экономические аспекты угрозы распространения ВИЧ/ СПИД в Российской Федераџии. Цель исследования - совершенствование системы социально-экономического мониторинга угрозы распространения ВИЧ/СПИД. Использована методология системного анализа и методы статистической обработки данных. Выделены три основных раздела сочиально-экономического мониторинга ВИЧ/СПИД, определены их проблемы, задачи и направления совершенствования. Сделан акиент на необходимости при оценке распространенности заболеваний и планировании расходов разграничивать зафиксированные случаи заболевания и скрытые случаи, характеризующие истинную заболеваемость. Результаты исследования применимы при обосновании и формировании государственной политики в области противодействия распространению ВИЧ/СПИД. Планирование расходов на мероприятия по противодействию угрозе должно базироваться на согласовании потребностей, выделяемых средств и достигаемых результатов. Системный подход к планированию расходов требует становления и развития методологии и методов соииально-экономического мониторинга в этой области. Отсутствие системного подхода к согласованию расходов и потребностей приводит к неэффективному расходованию ресурсов.
\end{abstract}

Ключевые слова: государственная политика, заболеваемость населения, распространенность заболеваний, социально-экономический мониторинг, угроза ВИЧ/СПИД

Угрозами национальной безопасности в сфере здоровья нации являются массовое распространение ВИЧ-инфекции, туберкулеза, наркомании, повышение доступности психоактивных и психотропных веществ [22].

По данным Федерального научно-методического центра по профилактике и борьбе со СПИД общее число россиян, инфицированных ВИЧ, зарегистрированных в РФ до 1 ноября 2011 г., составило 636979 человек. За 10 месяцев 2011 года территориальными центрами по профилактике и борьбе со СПИД было сообщено о 48363 новых случаях ВИЧ-инфекции среди граждан Российской Федерации. Ориентировочное число

\footnotetext{
1 Исследование поддержано Программой Президиума РАН «Фундаментальные науки - медицине», Проект Программы №5 «Многомасштабное моделирование защитных процессов при ВИЧ инфекции и идентификация критических параметров персистенции вирусов», проектом РФФИ №11-06-00454-а, федеральной целевой программой «Научные и научно-педагогические кадры инновационной России (2009-2013 гг.)».
}

зарегистрированных за 2011 г. новых случаев ВИЧ-инфекции составляет более 62 тыс. [21] и превосходит почти в 2 раза прогнозное значение этого показателя, указанное в 2007 году [8].

На слушаниях 2012 года в Общественной палате Российской Федерации, посвященных мерам по противодействию ВИЧ-инфекции в России и роли отечественных некоммерческих организаций в этой деятельности, отмечалась ошибочность положения о стабилизации эпидемического процесса, так как ежегодный прирост заболевших составляет более $10 \%$, число обследованных снижается, а число выявленных больных растет [14].

В докладе Объединенной программы ООН по ВИЧ/СПИД (UNAIDS / ЮНЭЙДС) за 2011 год [7] указывается, что этот год явился поворотным моментом в противодействии СПИДу, продемонстрировав небывалый прогресс в области науки, политического лидерства и результатов, однако в странах Восточной Европы и 
Центральной Азии в 2010 году по сравнению с 2001 годом число людей, живущих с ВИЧ, увеличилось на $250 \%$, почти $90 \%$ бремени региональной эпидемии приходится на Российскую Федерацию и Украину.

Развитие эпидемиологической ситуации по ВИЧ-инфекции в России свидетельствует об отсутствии признаков ее стабилизации [18]. Общие тенденции развития эпидемии ВИЧ-инфекции в РФ в последние годы остаются без изменений: эпидемия ширится, помимо продолжающегося распространения инфекции при потреблении наркотиков учащается и передача половым путем, увеличивается пораженность населения ВИЧ и количество смертей ВИЧ-позитивных лиц $[1,2]$.

На слушаниях 2011 года в Общественной палате Российской Федерации по проблемам и перспективам профилактики ВИЧ-инфекции в России высказывалась «озабоченность неточностью расчетов Минздравсоцразвития России при определении размеров субсидий регионам из федерального бюджета на приобретение жизненно важных для ВИЧ-инфицированных лиц диагностических препаратов» [18]. Ситуация усугубляется возникшими в последние годы перебоями в организации поставок антиретровирусных препаратов и средств диагностики, что привело как к перерывам в лечении части больных и нарушению схем лечения ВИЧинфицированных, так и уменьшению объемов тестирования [18]. Одной из ключевых причин ухудшения эпидемиологической ситуации является малый охват населения профилактическими программами, что связано как с недостаточным финансированием этих мероприятий, так и их неэффективной организацией, использованием не отвечающих принципам доказательной медицины и общепризнанным международным стандартам методик, а также с тенденцией к сворачиванию участия в программах профилактики общественных организаций [18].

В связи с высокой ответственностью государства за противодействие эпидемии вопросы социально-экономического мониторинга и оценки угрозы распространения ВИЧ/СПИД на территории России являются актуальными. Результаты социально-экономического мониторинга и оценки составляют информационную основу актуализации государственной политики противодействия эпидемии, профилактики и лечения ВИЧ/СПИД.

\section{Мониторинг распространения ВИЧ/СПИД: основные показатели и методики оценки угрозы распространения заболевания}

Основными статистическими показателями заболеваемости ВИЧ/СПИД, используемыми в международной статистике [27, 30], являются:

- модельные оценки истинной распространенности ВИЧ - HIV Prevalence Estimate;

- модельные оценки истинного числа новых случаев инфицирования ВИЧ (реально существующих, но не обязательно диагностированных случаев инфицирования ВИЧ), как правило, за один год - HIV Incidence Estimate;

- зарегистрированные случаи заболеваний ВИЧ/СПИД в данном году — New HIV/AIDS Cases;

- число зарегистрированных лиц, живущих с ВИЧ/СПИД, - Persons Living with HIV/AIDS;

- число лиц с диагнозом СПИД, умерших в данном году, - Deaths of Persons with AIDS.

Указанные показатели определяются для регионов, для различных групп населения (по полу, возрасту, факторам риска).

Координирующий центр Объединенной программы Организации Объединенных Наций по ВИЧ/СПИД (UNAIDS / ЮНЭЙДС), оценивая распространенность ВИЧ в России, приводит модельные данные на 2009 год о числе лиц, живущих с ВИЧ (number of people living with HIV), - 980000 человек, указывая возможный диапазон значений от 840000 до 1200000 человек. Показатель распространенности ВИЧ среди взрослого населения (от 15 лет и старше) составляет $0,9-1,2 \%$ [28, p. 188]. С учетом данных о зарегистрированных случаях инфицирования ВИЧ и числе умерших зафиксированная распространенность заболевания (пораженность населения) на 31.12.2010 г. составила 0,36\% [2, c. 49]. Наиболее высокие показатели зарегистрированной распространенности отмечены в возрастных группах 25-29 лет и 30-34 года: 1,57\% и $2,06 \%$ среди мужчин и $1,12 \%$ и $0,82 \%$ среди женщин соответственно.

На первый взгляд кажется, что характеристики эпидемического процесса ВИЧ/СПИД в России, указываемые зарубежными экспертами, существенно превышают аналогичные показатели отечественной статистики. На самом деле анализируются различные количественные аспекты эпидемии: количество зарегистрированных лиц и модельная оценка истинного числа больных и инфицированных. При характерис- 
тике распространенности ВИЧ-инфекции показатель «число больных» определяется в мировой и отечественной статистике по-разному.

В мировой статистике здравоохранения оценивается количество как зарегистрированных, так и невыявленных больных: «В странах с генерализированной эпидемией распространенность ВИЧ оценивается на основе данных об обращающихся в дородовые женские консультации и данных популяционных обследований. В случаях концентрированных и низкоуровневых эпидемий (когда распространенность ВИЧ среди беременных женщин ниже 1\%) оценки получают на основе эпидемиологического надзора за группами населения, где поведение сопряжено с повышенным риском» [10, с. 47]. В итоге зарубежная статистика о ВИЧ/СПИД при характеристике распространенности ВИЧ-инфекции (prevalence) и интенсивности появления новых случаев ВИЧ-инфицирования (incidence) использует оценки общего (суммарного) числа инфицированных (числа зарегистрированных больных и оцененного по моделям числа существующих, но не выявленных больных).

В Российской Федерации исходной информацией для мониторинга ВИЧ/СПИД, оценки и прогнозирования эпидемии служат статистические данные, сбор которых осуществляют центры по профилактике и борьбе со СПИД в субъектах Российской Федерации и территориальные управления Федеральной службы по надзору в сфере защиты прав потребителей и благополучия человека. Федеральная служба государственной статистики, характеризуя «распространенность вируса иммунодефицита человека» [5], приводит данные Минздравсоцразвития России о числе зарегистрированных лиц, в крови которых при исследовании методом иммунного блотинга выявлены антитела к ВИЧ.

Российская статистика аккумулирует данные о количестве новых диагностированных случаев инфицирования ВИЧ и заболевания СПИД, а также о накопленном количестве зарегистрированных инфицированных и больных. Эти показатели определяются для регионов РФ и некоторых групп населения. В международной статистике рассмотренные показатели характеризуются словосочетаниями «зарегистрированные диагнозы» (reported diagnoses), «количество случаев» (number of cases). В отечественных публикациях, как правило, количество новых диагностированных случаев инфицирования ВИЧ и за- болевания СПИД называется заболеваемостью, а накопленное количество зарегистрированных инфицированных и больных - распространенностью или пораженностью. В результате российские и международные показатели заболеваемости и распространенности ВИЧ/СПИД оказываются статистически несопоставимыми.

Следовательно, при оценке как заболеваемости, так и распространенности необходимо различать и анализировать, по крайней мере, по две характеристики: манифестная (зарегистрированная) заболеваемость и распространенность (определяемая по количество зарегистрированных лиц) и истинная заболеваемость и распространенность (определяемая по модельным оценкам истинного числа больных и инфицированных). Детальное обоснование целесообразности введения этих и ряда других показателей, позволяющих проводить мониторинг и статистический анализ заболеваемости, распространенности заболеваний, а также временных характеристик течения болезни рассмотрены в работах $[16,23,24,26]$. Таким образом, кажущаяся незначительной терминологическая неопределенность приводит к проблеме сопоставимости статистических данных и, как следствие, к проблеме обоснования финансирования мер и программ по противодействию эпидемии.

Отметим, что показатель распространенности заболевания мало информативен для однозначной оценки динамики эпидемии и эффективности ее профилактики, так как этот показатель отражает накопленное количество случаев заболевания с момента выявления первого случая. Высокое значение показателя распространенности заболевания ВИЧ, с одной стороны, может быть результатом интенсивного развития эпидемии в начальной стадии ее возникновения, с другой стороны, при оценке длительного эпидемического процесса может свидетельствовать об эффективности применения антиретровирусной терапии, продлевающей жизнь людям, живущим с ВИЧ.

Для текущего этапа развития эпидемии ВИЧ/ СПИД целесообразно анализировать показатель интенсивности появления новых случаев заражения в единицу времени, например, год, называемый в отечественной статистике здравоохранения показателем заболеваемости или первичной заболеваемости. Следует отметить, что указанный показатель в русскоязычном варианте доклада UNAIDS [7, с. 45] ошибочно назы- 
вается «показателем заражения» или «уровнем заражения». Исходный англоязычный термин «incidence» [29, p. 45] традиционно переводится как заболеваемость, отражает частоту или интенсивность появления новых случаев заболевания, как правило, за год.

Показатель заболеваемости отражает изменения в передаче ВИЧ, а также эффект от профилактических программ, включая эффект от осуществления программ антиретровирусной терапии.

В докладе Минздравсоцразвития России (2007 г.) о результатах и основных направлениях деятельности на 2008 год и на период до 2010 года были приведены данные об ожидаемой заболеваемости ВИЧ-инфекцией в плановом, на момент подготовки доклада, периоде - 2008-2010 годы. Показатели федеральной целевой программы «Предупреждение и борьба с социально значимыми заболеваниями (20072011 годы)» [8] прогнозировались в следующих объемах: абсолютное число вновь зарегистрированных в течение года случаев ВИЧ-инфекции в 2008 году - около 34 тыс. человек, в 2009 - 33 тыс., 2010 - 32 тыс. (табл.1, строка 1) Плановое значение показателя заболеваемости ВИЧ-инфекцией (число больных с впервые в жизни установленным диагнозом на 100 тыс. населения) на 2010 год составляло 21 случай на 100 тыс. населения (см. таблицу 1, строку 2), целевое значение - 17 случаев.

По мере регистрации новых случаев ВИЧинфицирования эти показатели были уточнены (см. таблицу 1, строки 3 и 4): в 2008 г. было зафиксировано 54647 новых случаев, в 2009 г. 58 410, в 2010 г. - 58426 [21]. Прогноз 2007 г. о спаде эпидемии к 2010 году не оправдался.

Последующие уточнения показателей заболеваемости ВИЧ в ФЦП «Предупреждение и борьба с социально значимыми заболеваниями (2007-2012 годы)» представлены в строках 5 и 6 таблицы 1 . В действующей редакции федеральной целевой программы планируется рост количества вновь зарегистрированных случаев заражения ВИЧ, что будет свидетельствовать, с учетом оценок UNAIDS, не столько о росте эпидемии, сколько о сокращении разрыва между числом зарегистрированных больных и истинным числом больных, т. е. о повышении выявляемости.

Заслуживают внимания различия в оценках заболеваемости, даваемых постфактум
Федеральным центром СПИД (строки 3 и 4) и Росстатом (строки 7 и 8), такие разночтения могут служить источником ошибок при планировании противоэпидемических программ и оценке их экономической эффективности.

При сравнении гендерной структуры ВИЧинфицированных, определенной по оценкам истинной заболеваемости (по данным UNAIDS [28]), и гендерной структуры заболеваемости для случаев зарегистрированной ВИЧ-инфекции [2], наблюдаются существенные различия.

По данным UNAIDS, среди взрослого населения, живущего с ВИЧ, доля женщин возросла с $44,2 \%$ в 2001 г. до $50 \%$ в 2009 г. [28]. По данным Федерального центра СПИД, к концу 2010 г. среди ВИЧ-инфицированных по-прежнему преобладали мужчины (64,9\%). С 2002 года отмечается увеличение доли женщин, к концу 2010 г. в России было зарегистрировано более 206 тысяч инфицированных женщин $(35,1 \%$ всех зарегистрированных случаев ВИЧ-инфекции) [2, с. 6].

Подход UNAIDS к моделированию эпидемии ВИЧ/СПИД основан на построении оценок распространенности эпидемического процесса с использованием данных об инфицировании определенных групп населения [6]. Компьютерные программы для оценки и прогнозирования позволяют построить эпидемическую кривую на основе данных, имеющихся в стране. Если в стране развивается генерализованная эпидемия, используются данные, полученные от центров женской консультации, о распространенности ВИЧ-инфекции среди беременных женщин, и любые данные общенациональных обследований. Если в стране концентрированная или умеренная эпидемия, используются данные о подгруппах, подвергающихся повышенному риску ВИЧ-инфекцирования. Данные о каждой подгруппе включают оценки их численности, данные эпиднадзора за ВИЧ в группе за определенный период времени и оценки числа представителей этих групп, получающих антиретровирусную терапию (АРТ).

Для генерализованных эпидемий и некоторых типов концентрированных эпидемий эти данные используются вместе с пакетом прогнозирования эпидемии с целью оценки распространенности инфицирования среди взрослого населения за определенный период времени.

Выходными данными, характеризующими последствия эпидемии, являются: число людей, живущих с ВИЧ, число новых случаев инфекции, 
Таблица 1

Динамика основных статистических показателей интенсивности распространения ВИЧ-инфекции в России

\begin{tabular}{|c|c|c|c|c|c|c|c|c|}
\hline № & Показатели & 2007 & 2008 & 2009 & 2010 & 2011 & 2012 & Источник данных \\
\hline 1 & $\begin{array}{l}\text { Число вновь зарегистриро- } \\
\text { ванных в течение года случаев } \\
\text { ВИЧ-инфекции - всего, тыс. } \\
\text { человек }\end{array}$ & 35 & 34 & 33 & 32 & & & $\begin{array}{l}\text { Минздравсоцразвития России, } \\
2007 \text { г., прогно3 на 2008-2010 } \\
\text { гг. [8] }\end{array}$ \\
\hline 2 & $\begin{array}{l}\text { Заболеваемость ВИЧ- } \\
\text { инфекцией, число больных с } \\
\text { впервые в жизни установлен- } \\
\text { ным диагнозом на } 100 \text { тыс. } \\
\text { населения }\end{array}$ & 25,0 & 22,9 & 21,7 & 21,0 & & & $\begin{array}{l}\text { Минздравсоцразвития России, } \\
2007 \text { г., прогно3 на 2008-2010 гг. } \\
\text { [12] }\end{array}$ \\
\hline 3 & $\begin{array}{l}\text { Число зарегистрированных } \\
\text { новых случаев ВИЧ-инфекции } \\
\text { среди российских граждан, } \\
\text { тыс. человек }\end{array}$ & 44,761 & 54,647 & 58,410 & 58,426 & & & $\begin{array}{l}\text { Федеральный центр СПИД, } \\
2010 \text { г., } 2011 \text { г. [1,2] }\end{array}$ \\
\hline 4 & $\begin{array}{l}\text { Число зарегистрированных } \\
\text { новых случаев ВИЧ-инфекции } \\
\text { на } 100000 \text { населения РФ (ис- } \\
\text { ключая детей с неустановлен- } \\
\text { ным диагнозом) }\end{array}$ & 31,5 & 38,4 & 41,2 & 41,2 & & & $\begin{array}{l}\text { Федеральный центр СПИД, } \\
2010 \text { г., } 2011 \text { г. [1,2] }\end{array}$ \\
\hline 5 & $\begin{array}{l}\text { Количество вновь зарегист- } \\
\text { рированных в течение года } \\
\text { случаев заражения ВИЧ- } \\
\text { инфекцией, тыс. человек }\end{array}$ & 35 & 46,8 & 55 & 63,5 & 64 & 65 & $\begin{array}{l}\text { ФЦП «Предупреждение и } \\
\text { борьба с социально значимыми } \\
\text { заболеваниями (2007 - } 2012 \\
\text { годы)» (с изменениями от } 18 \\
\text { февраля } 2008 \text { г., } 9 \text { апреля } 2009 \text { г., } \\
6 \text { апреля, } 28 \text { декабря } 2011 \text { г.) [3] }\end{array}$ \\
\hline 6 & $\begin{array}{l}\text { Количество вновь зарегист- } \\
\text { рированных в течение года } \\
\text { случаев заражения ВИЧ- } \\
\text { инфекцией в исправительных } \\
\text { учреждениях ФСИН России, } \\
\text { тыс. человек }\end{array}$ & 1,85 & 1,8 & 1,74 & 1,69 & 1,68 & 1,67 & $\begin{array}{l}\text { ФЦП «Предупреждение и } \\
\text { борьба с социально значимыми } \\
\text { заболеваниями }(2007-2012 \\
\text { годы)» (с изменениями от } 18 \\
\text { февраля } 2008 \text { г., } 9 \text { апреля } 2009 \text { г., } \\
6 \text { апреля, } 28 \text { декабря } 2011 \text { г.) [3] }\end{array}$ \\
\hline 7 & $\begin{array}{l}\text { Зарегистрировано больных с } \\
\text { диагнозом болезни, вызван- } \\
\text { ной ВИЧ, установленным } \\
\text { впервые в жизни, тыс. человек }\end{array}$ & 38,8 & 44,1 & 50,7 & 57,2 & & & $\begin{array}{l}\text { Минздравсоцразвития России, } \\
\text { расчет Росстата, } 2012 \text { г. [4] }\end{array}$ \\
\hline 8 & $\begin{array}{l}\text { Зарегистрировано больных с } \\
\text { диагнозом болезни, вызван- } \\
\text { ной ВИЧ, установленным } \\
\text { впервые в жизни на } 100000 \\
\text { человек населения }\end{array}$ & 27,3 & 31,1 & 35,7 & 40,0 & & & $\begin{array}{l}\text { Минздравсоцразвития России, } \\
\text { расчет Росстата, } 2012 \text { г. [4] }\end{array}$ \\
\hline
\end{tabular}

число ВИЧ-инфицированных беременных женщин, смертность, число смертей, обусловленных СПИД, потребности в лечении. Специалистами UNAIDS разработано программное обеспечение для картографирования эпидемий ВИЧ и определения последствий эпидемии.

Программа для оценки и прогнозирования последствий эпидемии доступна в Интернете на веб-сайтах http://www.HealtPolicyInitiative. com или www.FuturesInstitute.org [6]. Программа использует оценки числа новых случаев и производит подсчет дополнительных показателей, таких как количество инфицированных человек, число новых случаев инфицирования, случаи СПИД, смерти от СПИД, количество человек, которые испытывают потребность в лечении, и число сирот. Данные расчеты могут основываться на государственных демографических планах или на прогнозах и оценках населения, которые были подготовлены Отделом ООН по народонаселению.

Информация о моделях эпидемий (Отдел ООН по народонаселению) подготовлена справочной группой UNAIDS. Эти модели описывают процесс от инфицирования до смерти, распределение инфицирования по возрасту и полу, передачу ВИЧ от матери ребенку, а также влияние ВИЧ-инфекции на рождаемость и эффекты лечения. В моделях можно использовать данные для выявления различий между эпидемиями в 
городах и сельской местности или между разными регионами.

Для стран, в которых распространенность ВИЧ-инфекции среди взрослого населения превышает несколько процентов, рекомендуется вначале разработать демографический прогноз без учета воздействия СПИД, затем сделать предположения относительно будущего уровня распространенности ВИЧ-инфекции среди взрослого населения, далее подробно рассмотреть последствия СПИД в демографическом прогнозе ${ }^{1}$, поскольку они сказываются на возрастной схеме смертности (смертность от СПИД сосредоточена в возрастных группах 15-49 лет).

Качество и точность оценок зависят от качества и точности данных, использованных для построения моделей. Если в стране имеется очень мало информации о распространенности ВИЧ, модель будет в большой степени зависеть от допущений о данных, которые будут использоваться при моделировании. С другой стороны, страны, в которых регулярно проводился плановый эпиднадзор или частые обследования, охватывающие группы, играющие наиболее значительную роль в развитии эпидемии, могут проводить моделирование на основе значительных объемов данных, благодаря чему получать высококачественные оценки и прогнозы.

Таким образом, проведенное исследование показало, что мониторинг угрозы распространения ВИЧ/СПИД в Российской Федерации связан с необходимостью решения проблемы фрагментарности данных. Статистические данные имеют фрагментарный характер, что вызвано следующими основными причинами:

- процедуры сбора и регистрации первичных данных, применяемых в различных организациях, не согласованы по временным интервалам, по учитываемым характеристикам групп риска и фокус-групп;

- процедуры сбора и регистрации первичных данных претерпевают изменения с течением времени;

- информация о характеристиках эпидемического процесса утрачивается при сборе и обобщении данных на различных уровнях управления.

\footnotetext{
1 ДемПродж: Версия 4: Компьютерная программа для составления демографических прогнозов в «Система политических моделей „Спектрум” (подготовил Джон Стоувер The Futures Group International и Шэрон Кирмайер Исследовательский институт Triangle).
}

К аналогичным выводам приходят и авторы работы [25, с. 66-67], указывая на «раздробленность сбора и анализа данных», обусловленную следующими обстоятельствами. Данные по ВИЧ-инфекции, а также инфекциям, передаваемым половым путем, туберкулезу, (инъекционным) наркотикам и другим вопросам собираются под контролем различных медицинских учреждений, подчиненных региональным отделам здравоохранения. Хотя эти данные поступают в разные организации регионального уровня, а также через специализированные научные центры распространяются на федеральном уровне, раздробленность данных мешает эффективному соединению воедино всех их подгрупп. Похожим образом недостаточный сбор поведенческих данных не позволяет проводить систематический анализ основных факторов риска ВИЧ-инфицирования.

Отсутствуют точные оценки истинной распространенности (prevalence) ВИЧ/СПИД с учетом незарегистрированных случаев, а также истинного количества инфицированных ВИЧ за непродолжительный период времени (incidence), например, за год. Рекомендуемые UNAIDS модели и методики расчета указанных оценок имеют слишком общий и субъективный характер и недостаточно адаптированы для РФ.

Кроме того, на сегодняшний день в России нет четкой терминологии заболеваемости ВИЧ/ СПИД, сопоставимой с международной, и нет однозначной интерпретации характеристик, необходимых для суждения об угрозе развития эпидемии и оценки сопутствующих социальноэкономических рисков.

\section{Мониторинг расходов на предотвращение угрозы распространения ВИЧ/СПИД: основные источники финансирования, динамика и структура расходов}

Координирующим центром Объединенной программы ООН по ВИЧ/СПИД в декабре 2010 года принята стратегия действий на 20112015 годы «Getting to zero: 2011-2015 strategy Joint United Nations Programme on HIV/AIDS (UNAIDS)» [27], предусматривающая осуществление комплекса мер по предотвращению эпидемии ВИЧ/СПИД в новых глобальных условиях, по обеспечению всеобщего доступа к профилактике, лечению и поддержке ВИЧ инфицированных и больных СПИД. 


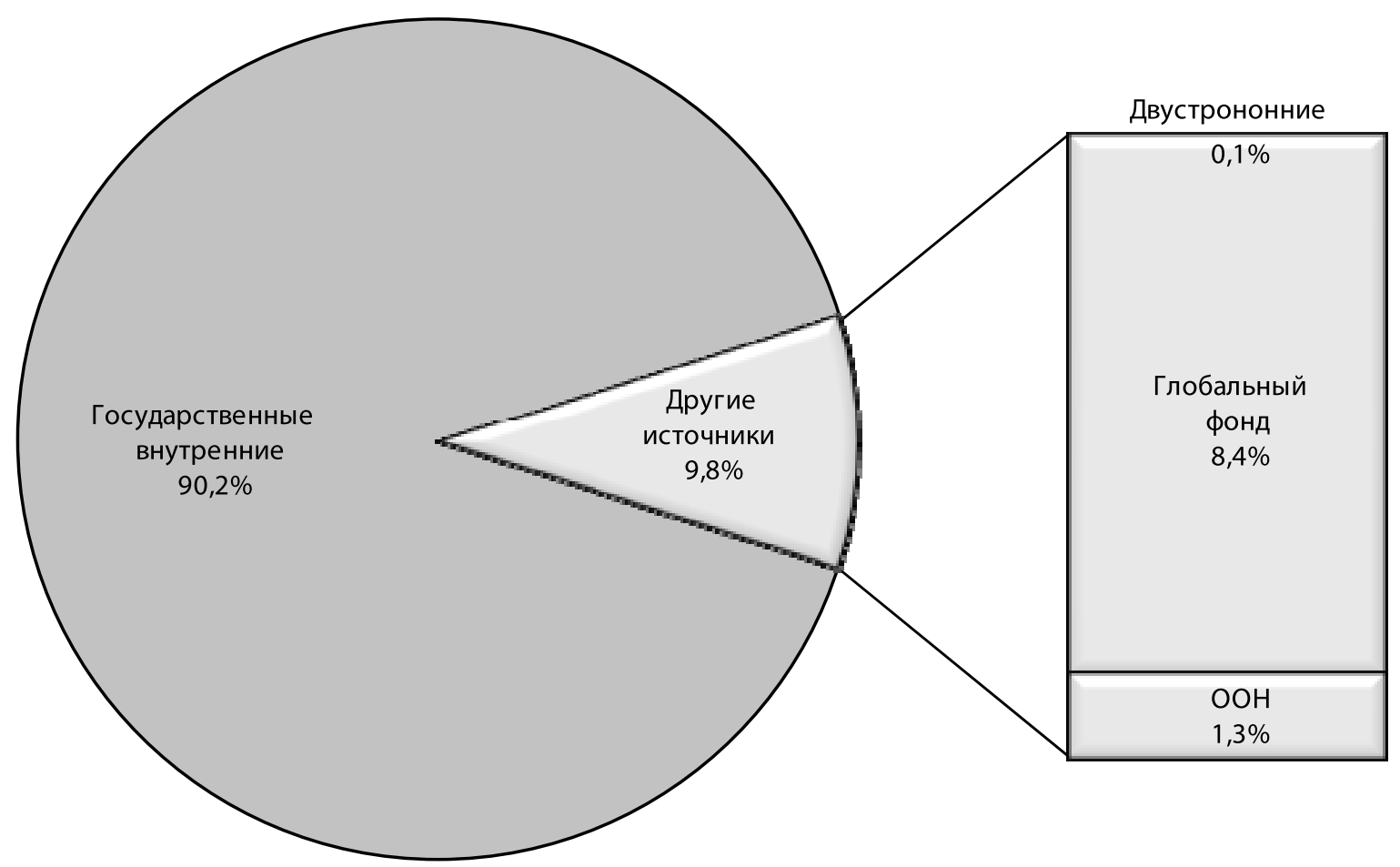

Рис. 1. Источники финансирования мероприятий по предотвращению угрозы распространения ВИЧ/СПИД, 2008 г., по данным [28, p. 230-231]

По данным UNAIDS [28] сумма внутренних государственных и международных средств, израсходованных Россией в 2008 году на профилактику и лечение ВИЧ/СПИД, составила 777,021 млн долл. США, 90,2\% из них - внутренние государственные средства (рис.1).

Основное финансирование мероприятий, направленных на предотвращение угрозы распространения ВИЧ/СПИД, осуществляется в рамках приоритетного национального проекта «Здоровье», подпрограммы «ВИЧ-инфекция», включенной в федеральную целевую программу «Предупреждение и борьба с социально значимыми заболеваниями (2007-2012 годы)». Динамика расходования бюджетных средств на предотвращение угрозы распространения ВИЧ/ СПИД представлена в табл. 2.

На рис. 2 приведена структура расходования средств приоритетного национального проекта «Здоровье», подпрограммы «ВИЧ-инфекция», ФЦП «Предупреждение и борьба с социально значимыми заболеваниями (2007-2012 годы)» на предотвращение угрозы распространения ВИЧ/СПИД в 2011-2012 гг. Значительный объем средств расходуется на обследование населения с целью выявления ВИЧ-инфицированных, гепатитов В и $\mathrm{C}$, а также лечение больных ВИЧинфекцией, гепатитами В и С, включая закупки диагностических средств и антиретровирусных препаратов.

Общий объем финансирования подпрограммы «ВИЧ-инфекция» за 2011-2012 гг. составляет 10623,7954 млн руб. (в ценах соответствующих лет), в том числе за счет средств: федерального бюджета - 5487,0954 млн руб.; бюджетов субъектов Российской Федерации 4940,7 млн руб.; внебюджетных источников 196 млн рублей [13].

Реализация подпрограммы осуществляется на основе государственных контрактов, заключенных государственными заказчиками с исполнителями мероприятий подпрограммы в соответствии с Федеральным законом «О размещении заказов на поставки товаров, выполнение работ, оказание услуг для государственных и муниципальных нужд», а также в порядке межбюджетных отношений в соответствии с Бюджетным кодексом Российской Федерации.

В рамках реализации мероприятий подпрограммы предусматриваются [13]: строительство и реконструкция специализированных учреждений; проведение научных исследований по проблеме ВИЧ-инфекции; совершенствование методов профилактики, диагностики и лечения заболевания, вызываемого вирусом иммунодефицита человека; развитие единой системы мо- 
Таблица 2

Динамика расходования бюджетных средств на предотвращение угрозы распространения ВИЧ/СПИД

\begin{tabular}{|c|c|c|c|c|c|c|c|c|}
\hline № & $\begin{array}{c}\text { Наименование направ- } \\
\text { ления, показателя }\end{array}$ & 2007 & 2008 & 2009 & 2010 & 2011 & 2012 & Источник данных \\
\hline 1 & $\begin{array}{l}\text { ФЦП «Предупреждение } \\
\text { и борьба с социально } \\
\text { значимыми заболевани- } \\
\text { ями (2007-2012 годы)», } \\
\text { подпрограмма «ВИЧ- } \\
\text { инфекция», млн руб. }\end{array}$ & 1101,2 & 1255,4 & 1179,096 & 1759,698 & 2237,182 & 3091,22 & $\begin{array}{l}\text { Минздравсоцразвития } \\
\text { России, } 2011 \text { г. [15] }\end{array}$ \\
\hline 2 & $\begin{array}{l}\text { ФЦП «Предупреждение } \\
\text { и борьба с социально } \\
\text { значимыми заболевани- } \\
\text { ями (2007-2011 годы)», } \\
\text { подпрограмма «ВИЧ- } \\
\text { инфекция», мл руб. }\end{array}$ & 321,0 & 447,0 & 359,0 & 1598,2 & & & $\begin{array}{l}\text { Доклад } \\
\text { Минздравсоцразвития } \\
\text { России, } 2007 \text { г., план на } \\
\text { 2008-2010 гг. [17] }\end{array}$ \\
\hline 3 & $\begin{array}{l}\text { Национальный проект в } \\
\text { сфере здравоохранения: } \\
\text { обследование населения } \\
\text { с целью выявления ин- } \\
\text { фицированных ВИЧ и } \\
\text { гепатитов В и С, а также } \\
\text { лечение больных ВИЧ- } \\
\text { инфекцией, гепатитами } \\
\text { В и С; централизованные } \\
\text { закупки диагности- } \\
\text { ческих средств и АРТ- } \\
\text { препаратов для профи- } \\
\text { лактики, выявления и } \\
\text { лечения инфицирован- } \\
\text { ных ВИЧ и гепатитов В, } \\
\text { С, млн руб. }\end{array}$ & $\begin{array}{c}7557 \\
{[17]}\end{array}$ & $\begin{array}{c}7600 \\
{[17]}\end{array}$ & $\begin{array}{c}8900 \\
{[19]}\end{array}$ & $\begin{array}{c}10524 \\
{[17]}\end{array}$ & $\begin{array}{c}15647 \\
{[20]}\end{array}$ & $\begin{array}{c}1910 \\
{[14]}\end{array}$ & $\begin{array}{l}\text { Доклад } \\
\text { Минздравсоцразвития } \\
\text { России, } 2007 \text { г., прогноз на } \\
2008-2010 \text { гг. [17] } \\
\text { Сведения о параметрах } \\
\text { реализации приоритет- } \\
\text { ного национального про- } \\
\text { екта «Здоровье» [19, 20] }\end{array}$ \\
\hline 4 & $\begin{array}{l}\text { Национальный проект в } \\
\text { сфере здравоохранения: } \\
\text { мероприятия по профи- } \\
\text { лактике ВИЧ-инфекции, } \\
\text { гепатитов В, С, млн руб. }\end{array}$ & $\begin{array}{c}220,7 \\
{[17]}\end{array}$ & $\begin{array}{l}200 \\
{[17]}\end{array}$ & $\begin{array}{l}399 \\
{[19]}\end{array}$ & $\begin{array}{c}400 \\
{[17] 17}\end{array}$ & $\begin{array}{l}144 \\
{[20]}\end{array}$ & & $\begin{array}{l}\text { Доклад } \\
\text { Минздравсоцразвития } \\
\text { России, } 2007 \text { г., прогноз на } \\
2008-2010 \text { гг. [17] } \\
\text { Сведения о параметрах } \\
\text { реализации приоритет- } \\
\text { ного национального про- } \\
\text { екта «Здоровье» }[19,20]\end{array}$ \\
\hline
\end{tabular}

ниторинга и оценки в области противодействия ВИЧ-инфекции. Планируемая динамика финансирования мероприятий подпрограммы приведена на рис. 3.

Ожидаемые конечные результаты реализации подпрограммы «ВИЧ-инфекция» и показатели еe социально-экономической эффективности: увеличение числа вновь зарегистрированных в течение года случаев заражения ВИЧ-инфекцией до 65 тыс. (за счет более полного выявления случаев инфицирования); снижение числа вновь зарегистрированных в течение года случаев заражения ВИЧ-инфекцией в исправительных учреждениях Федеральной службы исполнения наказаний до 1,67 тыс. случаев; увеличение доли ВИЧ-инфицированных беременных женщин, включенных в программу профилактики заражения ВИЧ-инфекцией новорожденных, до $95 \%$. Предполагаемый экономический эффект от снижения заболеваемости ВИЧ-инфекцией женщин репродуктивного возраста и повышения числа ВИЧ-инфицированных, получающих антиретровирусные препараты, составит 37,3 млрд рублей. Планируется, что социальная эффективность реализации мероприятий подпрограммы будет выражена в улучшении качества и увеличении продолжительности жизни больных, повышении информированности населения и формировании здорового образа жизни, снижении социальной и психологической напряженности в обществе вследствие угрозы распространения ВИЧ-инфекции [13].

Данные, приведенные на рис. 2 и 3, свидетельствуют, что на развитие единой системы мо- 


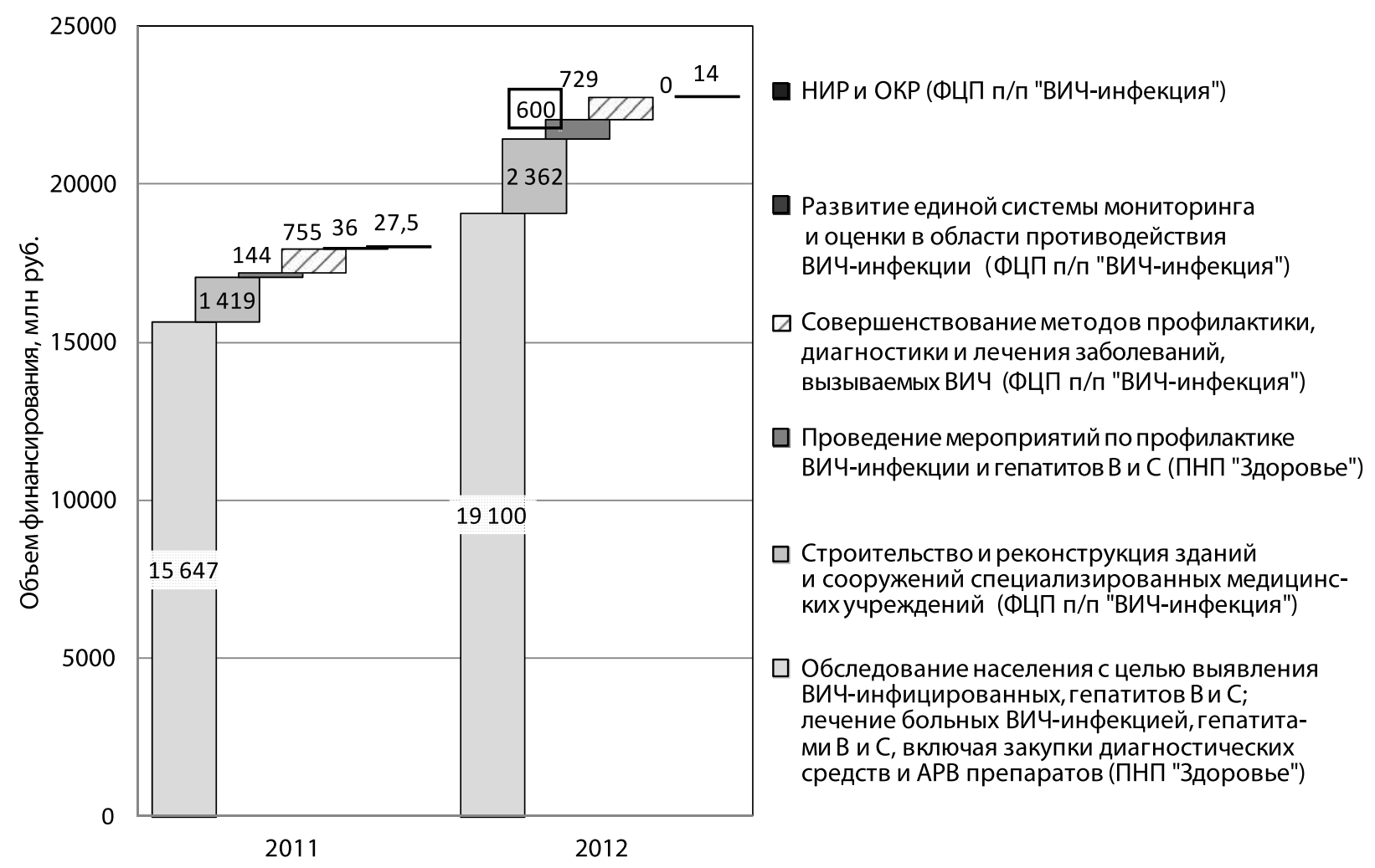

Рис. 2. Структура расходования средств приоритетного национального проекта «Здоровье», подпрограммы «ВИЧинфекция», ФЦП «Предупреждение и борьба с социально значимыми заболеваниями (2007-2012 годы)» на предотвращение угрозы распространения ВИЧ/СПИД в 2011-2012 г2. (по данным [14, 15, 20])

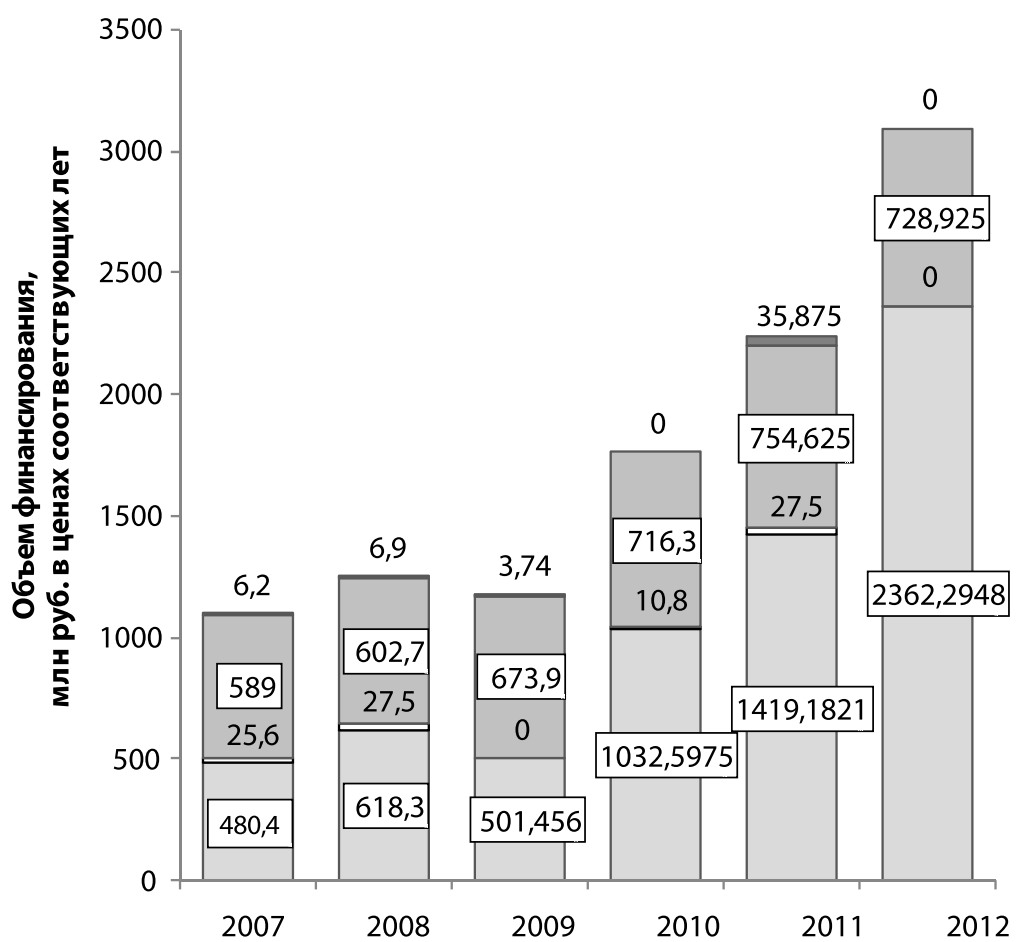

Развитие единой системы мониторинга и оценки в области противодействия ВИЧ-инфекции

Совершенствование методов профилактики, диагностики и лечения заболеваний, вызываемых вирусом иммунодефицитачеловека

Научно-исследовательские и опытноконструкторские работы

троительство и реконструкция зданий и сооружений специализированных медицинских учреждений

Рис. 3. Динамика структуры расходов подпрограммы «ВИЧ-инфекция» ФЦП «Предупреждение и борьба с социально значимыми заболеваниями (2007-2012 годы)», по данным [15]

ниторинга и оценки в области противодействия ВИЧ-инфекции, на научно-исследовательские и опытно-конструкторские работы средства выделяются не всегда.
Структура расходов на мероприятия по предотвращению угрозы распространения ВИЧ/ СПИД в Российской Федерации по данным UNAIDS [28] приведена на рис. 4. Расходы на 


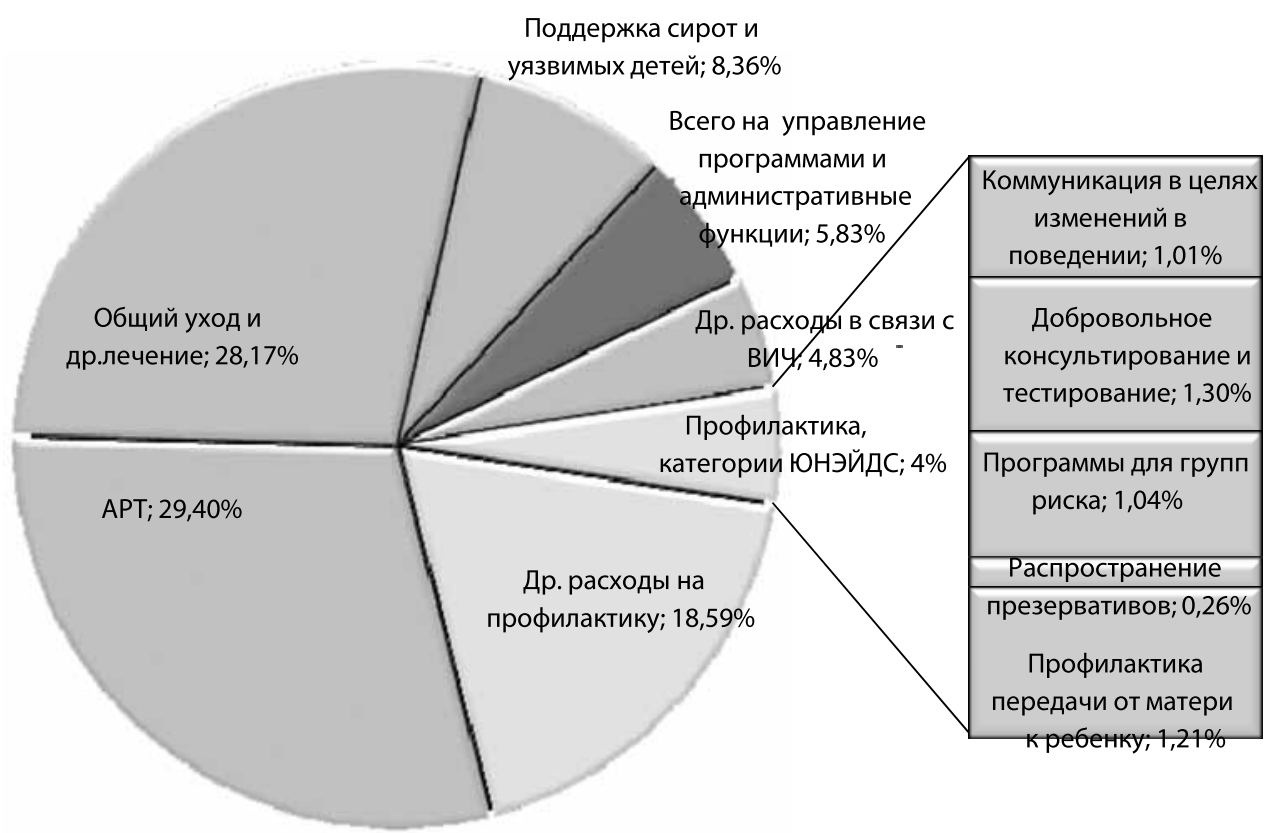

Рис. 4. Структура расходов на мероприятия по предотвращению угрозы распространения ВИЧ/СПИД, 2008 г., по данным [28, p. 230-231]

профилактику ВИЧ по наиболее важным категориям, соответствующим классификации UNAIDS, составляют 4\%, в то время как $18,59 \%$ всех средств составляют другие расходы на профилактику.

Более половины средств расходуется на уход и лечения, включая антиретровирусную терапию. Расходы на антиретровирусную терапию составляют $29,4 \%$.

По данным UNAIDS [28, p. 273], в 2009 году в Российской Федерации антиретровирусную терапию для предотвращения заражения ребенка получали от $57 \%$ до более $95 \%$ беременных женщин. Для косвенной оценки эффективности проводимой терапии может служить отношение количества рожденных детей с подтвержденным диагнозом ВИЧ-инфекция, инфицированных от ВИЧ-позитивных матерей, к количеству детей, рожденных от ВИЧ-инфицированных матерей, поставленных на диспансерное наблюдение до установления диагноза ВИЧ-инфекция. Сведения могут быть получены по данным Федерального центра СПИД [2] о кумулятивном количестве детей на 31 декабря соответствующего года. В 2009 г. значение этого показателя составляло $10,4 \%$ (245/4326), в 2010 г. снизилось до $5,7 \%$ (245/4326).

Средства на лечение ВИЧ-инфицированных антиретровирусными препаратами, по оценкам UNAIDS [28], выделяются в недостаточном объеме: в 2009 г. лечение получали 75900 человек, что составляет только 16-23\% количества всех нуждающихся в терапии в соответствии с рекомендациями ВО3 2010 года [28]. Количество сохраненных лет жизни лицам, живущим с ВИЧ, составило 65 тыс. лет [28]. В декабре 2011 года на сайте Минздравсоцразвития http://www. minzdravsoc.ru опубликован проект приказа «Об утверждении Порядка оказания медицинской помощи взрослому населению при болезни, вызванной вирусом иммунодефицита человека (ВИЧ-инфекции)», который предлагается к обсуждению. В проекте регламентируется доступ к антиретровирусной терапии.

Еще одна социальная проблема, обусловленная распространением эпидемии ВИЧ, - появление сирот. По оценкам UNAIDS [28], количество сирот в связи с ВИЧ в возрасте до 18 лет составляет от 27 тыс. до 50 тыс. человек, наиболее правдоподобная оценка - 37 тыс. человек. Расходы на поддержку сирот и уязвимых детей составили за 2008 г. 64,972 млн долл. США [28] (1 770499 млн руб. [11]).

В Российской Федерации расходы на предотвращение угрозы ВИЧ/СПИД в 2008 г. составили 777 млн долл. США, что составляет примерно половину от общего объема средств, который, по прогнозу UNAIDS, потребуется в 2015 г. Тем не менее, число новых ВИЧ-инфекций растет, поскольку небольшая часть всех средств выделяется на программы профилактики для групп риска. Из 181 млн долл. США, потраченных на программы профилактики ВИЧ в 2008 г., лишь 8 млн долл. были выделены для этих групп 


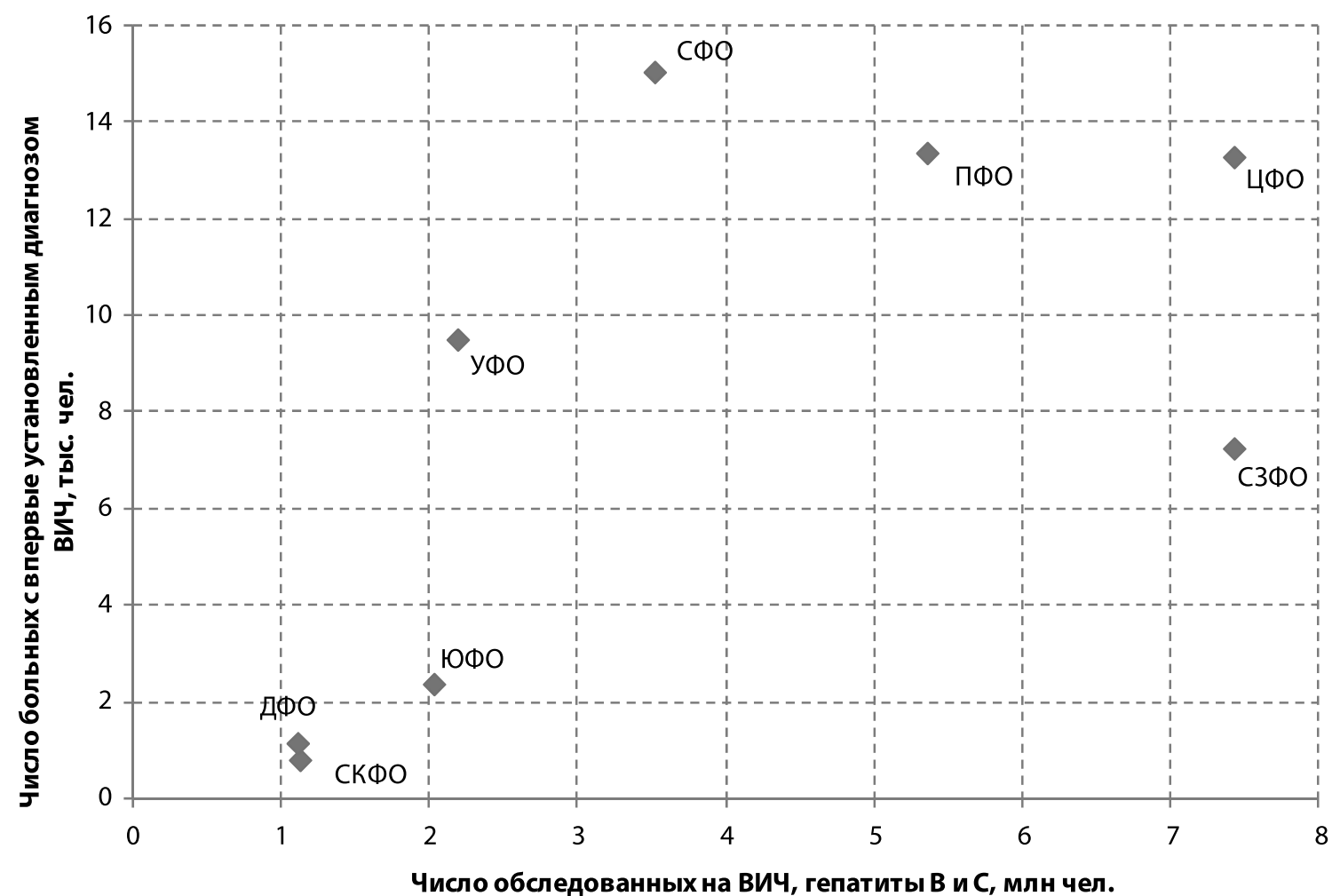

Рис. 5. Соотношение числа больных с впервые установленным диагнозом ВИЧ с числом обследованных на ВИЧ, гепаmuты $B$ и $C$

населения [7]. Изменение приоритетов в выделении имеющихся ресурсов может привести к существенному сокращению числа новых ВИЧ-инфекций.

\section{Мониторинг региональной дифференциации угрозы распространения ВИЧ/СПИД и реализуемых мер по ее предотвращению}

Характеристики эпидемического процесса ВИЧ/СПИД существенно различаются в регионах Российской Федерации, поэтому при планировании мероприятий по предотвращению угрозы распространения ВИЧ/СПИД необходимо учитывать региональную специфику. Необходимо сопоставлять и одновременно анализировать данные о первичной заболеваемости и распространенности ВИЧ/СПИД для различных половозрастных и поведенческих групп населения в регионах, об охвате различных групп населения тестированием на ВИЧ, о расходах на профилактику и лечение. Для осуществления анализа предлагается использовать регрессионные и кластерные модели. Далее рассматриваются примеры применения моделей для обобщенного анализа дифференциации федеральных округов и построения типологии регионов по наиболее информативным показателям распространения эпидемии.
На рис. 5 приведено соотношение числа больных с впервые установленным диагнозом ВИЧ с числом обследованных на ВИЧ, гепатиты В и С (выделяется Сибирский федеральный округ, для которого отмечается наибольшее отношение количества новых диагнозов к количеству обследованных. Целесообразно выделять дополнительные средства для более широкого охвата населения тестированием в этом федеральном округе.

На рис. 6 приведена регрессионная зависимость расходов на выявление ВИЧ-инфекции, гепатитов В и С и лечение от числа живущих с ВИЧ. Анализ рисунка показывает, что в соответствии с уровнем распространения ВИЧ целесообразно увеличить расходы на профилактику ВИЧ/СПИД в Северо-Западном, Уральском и Сибирском федеральных округах.

На рис. 7 приведена зависимость расходов на обследование населения с целью выявления ВИЧинфицированных, гепатитов В и С, а также лечение больных ВИЧ-инфекцией (площадь кружков, тыс. руб.), от количества живущих с ВИЧ и новых диагнозов ВИЧ. В Сибирском федеральном округе наблюдается самое высокое количество новых случаев инфицирования ВИЧ и достаточно большое число лиц, живущих с ВИЧ, средства на лечение которых, по-видимому, недостаточны. 


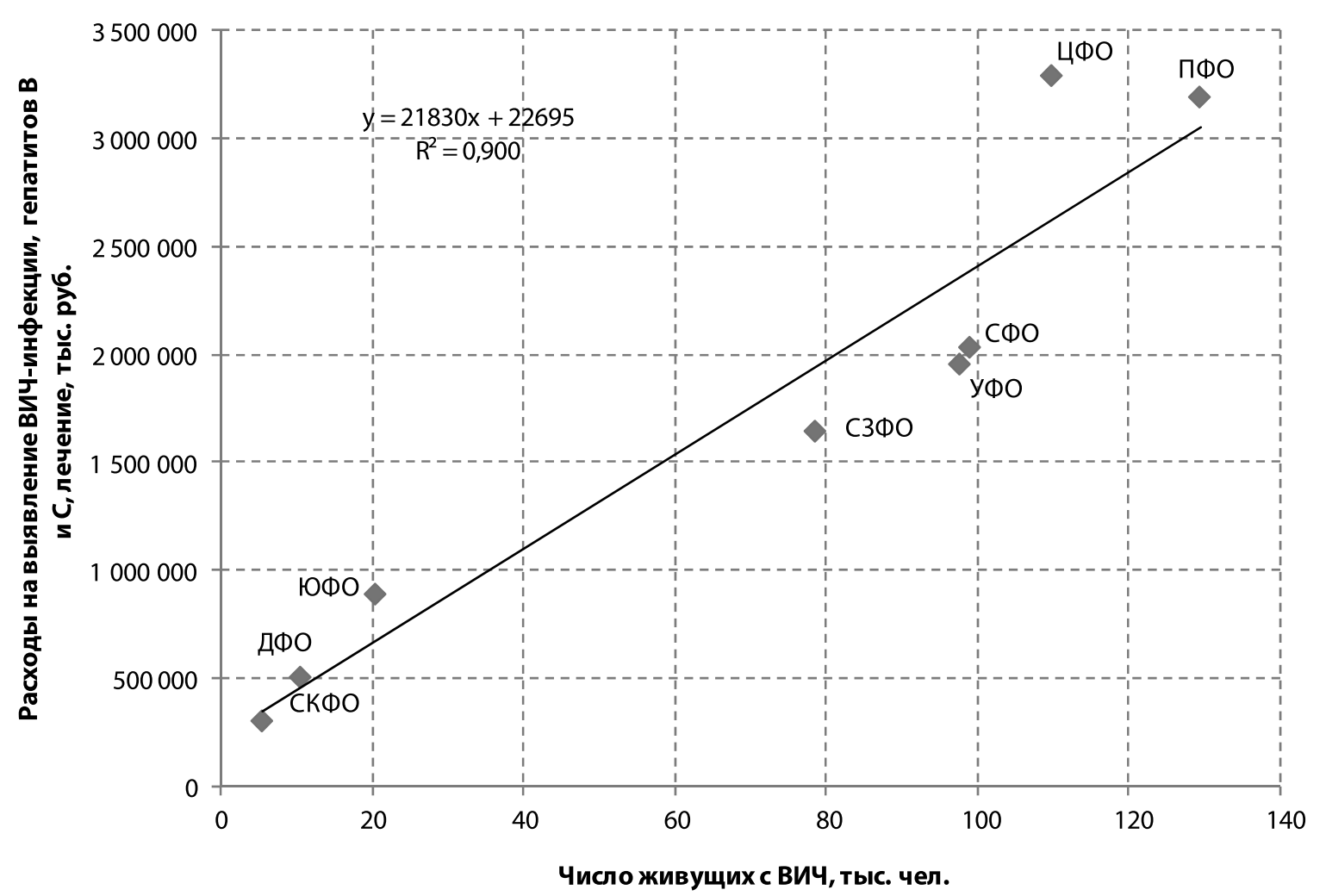

Рис. 6. Регрессионная модель зависимости расходов на выявление ВИЧ-инфекции, гепатитов В и С и лечение от числа живущих с ВИЧ

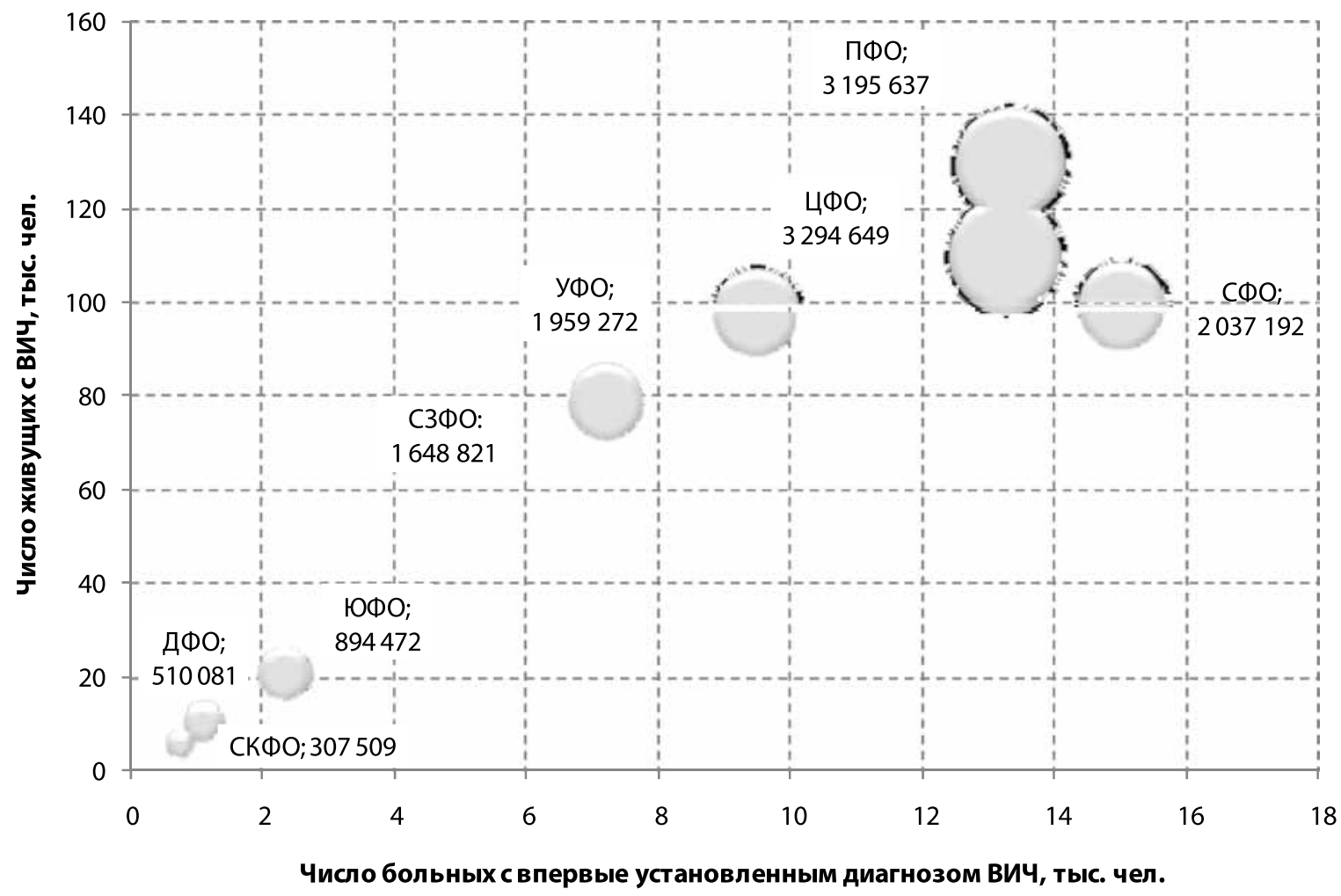

Рис. 7. Зависимость расходов на обследование населения с челью выявления ВИЧ-инфицированных, гепатитов B и C, a также лечение больных ВИЧ-инфекцией (площадь кружков, тыс. руб.) от количества живущих с ВИЧ и новых диагнозов BИЧ

Для построения типологии регионов по важнейшим показателям заболеваемости и распространенности ВИЧ/СПИД использован метод кластерного анализа $k$-средних. Рассмотрены показатели за 2010 год: количество зарегистрированных новых случаев инфекции у взрослых 


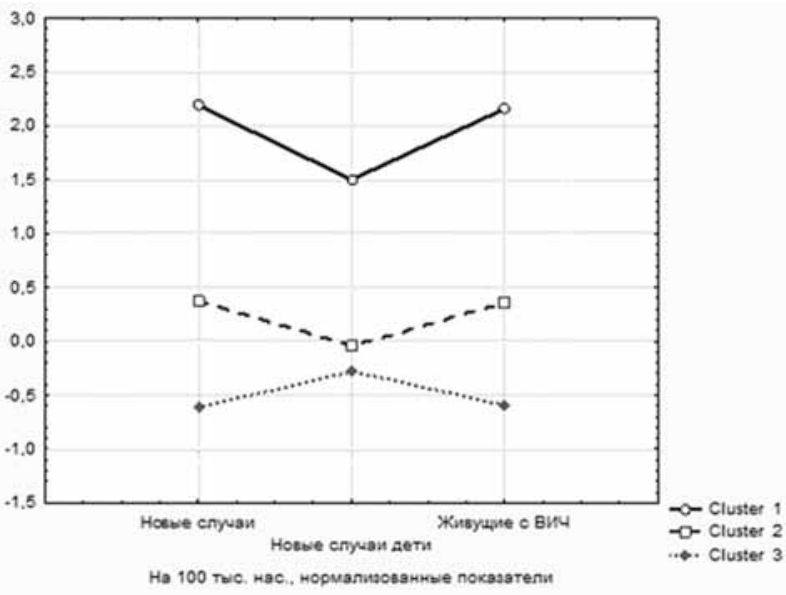

Рис. 8. Средние значения показателей заболеваемости и распространенности ВИЧ/СПИД для выделенных кластеров

и у детей до 15 лет (на 100000 соответствующего населения), число лиц, живущих с ВИЧ (на 100000 населения региона). Для проведения кластерного анализа указанные показатели нормализованы, в частности, средние значения нормализованных показателей по всем регионам равны 0 .

В результате выделены три кластера: с высокими, средними и низкими значениями показателей (рис. 8). Построенная типология может быть использована при планировании расходов на мероприятия по предотвращению угрозы распространения ВИЧ, СПИД.

В состав первого кластера входят: Ленинградская область, г. Санкт-Петербург, Оренбургская область, Самарская область, Ульяновская область, Свердловская область, ХантыМансийский АО, Иркутская область, Кемеровская область, Новосибирская область.

В состав второго кластера входят: Ивановская область, Московская область, Тверская область, Тульская область, г. Москва, Калининградская область, Мурманская область, Республика Башкортостан, Удмуртская Республика, Пермский край, Нижегородская область, Саратовская область, Курганская область, Тюменская область, Ямало-Ненецкий АО, Челябинская область, Республика Бурятия, Алтайский край, Забайкальский край, Красноярский край, Омская область, Приморский край, Чукотский авт.округ.

В состав третьего кластера входят: Белгородская область, Брянская область, Владимирская область, Воронежская область, Калужская область, Костромская область, Курская область, Липецкая область, Орловская область, Рязанская область, Смоленская область, Тамбовская об- ласть, Ярославская область, Республика Карелия, Республика Коми, Архангельская область, Ненецкий АО, Вологодская область, Новгородская область, Псковская область, Республика Адыгея, Республика Калмыкия, Краснодарский край, Астраханская область, Волгоградская область, Ростовская область, Республика Дагестан, Республика Ингушетия, Кабардино-Балкарская Республика, Карачаево-Черкесская Республика, Республика Северная Oceтия - Алания, Чеченская Республика, Ставропольский край, Республика Марий Эл, Республика Мордовия, Республика Татарстан, Чувашская Республика, Кировская область, Пензенская область, Республика Алтай, Республика Тыва, Республика Хакасия, Томская область, Республика Саха (Якутия), Камчатский край, Хабаровский край, Амурская область, Магаданская область, Сахалинская область, Еврейская автономная область.

\section{Выводы}

Планирование расходов на мероприятия по противодействию угрозе распространения ВИЧ/ СПИД, несмотря на достижения в лечении и профилактике заболевания, должно базироваться на согласовании потребностей, выделяемых средств и достигаемых результатов. Системный подход к планированию расходов требует становления и развития методологии и методов социально-экономического мониторинга в этой области. Отсутствие системного подхода к согласованию расходов и потребностей приводит к неэффективному расходованию ресурсов.

При системном планировании расходов на мероприятия по противодействию угрозе распространения ВИЧ/СПИД необходимо следовать следующим принципам:

- обеспечение максимальной результативности от осуществления мер в ответ на ВИЧ;

- всесторонний учет и анализ данных регионального эпидемиологического надзора для рационального выделения ресурсов;

- стимулирование регионов к развитию экономически эффективных, с учетом региональной специфики, программ предотвращения угрозы ВИЧ/СПИД;

- усиление медико-социальной эффективности профилактики, лечения, ухода и поддержки в связи с ВИЧ.

Наиболее рациональное расходование средств на меры по противодействию угрозе 
распространения ВИЧ/СПИД можно обеспечить за счет своевременного вложения средств там, где они действительно нужны; правильного выбора стратегий; повышения эффективности, сокращения затрат и развития инноваций.

Целесообразно сочетать централизованное планирование и финансирование мероприятий на федеральном уровне с дифференцированными стратегиями противодействия угрозе на региональном уровне.

Актуальны частные задачи развития системы социально-экономического мониторинга по противодействию угрозе распространения ВИЧ/ СПИД, которые можно классифицировать в соответствии с определенными выше разделами мониторинга:

a) мониторинг распространения ВИЧ/ СПИД, в частности:

- унификация показателей для оценки заболеваемости населения с целью предотвращения ошибок, связанных с неоднозначной трактовкой используемых терминов;
- разработка и верификация моделей и методик оценки характеристик эпидемического процесса, в том числе, характеристик распространенности случаев заболеваний и интенсивности появления новых случаев инфицирования, временных характеристик развития эпидемии и течения заболевания;

б) мониторинг расходов на предотвращение угрозы распространения ВИЧ/СПИД, в частности:

- введение единой системы целевых показателей и категорий затрат для всех программ, связанных с противодействием угрозе ВИЧ/СПИД;

- уточнение категорий затрат для средств, выделяемых на профилактику ВИЧ;

в) мониторинг региональной дифференциации угрозы распространения ВИЧ/СПИД и реализуемых мер по ее предотвращению, в частности, проведение динамической типологизации регионов по показателям распространения ВИЧ/СПИД с целью формирования региональных стратегий противодействия угрозе.

\section{Список источников}

1. ВИЧ-инфекция. Информационный бюллетень №34 / В. В. Покровский, Н. Н. Ладная, Е. В. Буравцова. - М. 2010.52 c. [Электронный ресурc]. URL: http://www.hivrussia.ru/files/bul_34.pdf.

2. ВИЧ-инфекция. Информационный бюллетень №35 / В. В. Покровский, Н. Н. Ладная, Е. В. Соколова, Е. В. Буравцова. — M., 2011. 51 с. [Электронный ресурc]. URL: http://www.hivrussia.ru/files/bul_35.pdf.

3. Динамика целевых индикаторов и показателей федеральной целевой программы «Предупреждение и борьба с социально значимыми заболеваниями (2007-2012 годы)» (с изменениями от с изменениями от 18 февраля 2008 г., 9 апреля 2009 г., 6 апреля, 28 декабря 2011 г.): Приложение № 1 к федеральной целевой программе «Предупреждение и борьба с социально-значимыми заболеваниями (2007-2012 годы)». [Электронный pecypc]. URL: http://base.garant.ru/4184672/\#10000.

4. Заболеваемость населения социально значимыми болезнями (данные Минздравсоцразвития России, расчет Росстата). - M.: Росстат, 2012. [Электронный ресурc]. URL: http://www.gks.ru/free_doc/new_site/population/zdrav/zdr2-2. xls.

5. Здравоохранение в России. 2009 : стат. сб. / Росстат. - М., 2009. - 356 с.

6. Инструктивные документы по применению инструментов для оценки и прогнозирования. Проект. - UNAIDS, $2009-49$ c.

7. Как прийти к цели «ноль». Быстрее. Разумнее. Лучше. Доклад ЮНЭЙДС к всемирному дню борьбы со СПИДом, 2011. [Электронный ресурс]. URL: http://www.unaids.ru/sites/default/files/doklad_yuneyds_k_vsemirnomu_dnyu_borby_so_ spidom._2011.pdf.

8. Краткая характеристика действующей и (или) планируемой бюджетной целевой программы, в части, касающейся отчетного периода: ФЦП «Предупреждение и борьба с социально значимыми заболеваниями (2007-2011 годы)»: Приложение № 4 к Докладу о результатах и основных направлениях деятельности Минздравсоцразвития России на 2008 год и на период до 2010 года. [Электронный ресурс]. URL: http://www.minzdravsoc.ru/ministry/budget.

9. Методология оценивания и анализа общественного здоровья / В. В. Уйба, Г. К. Максимов, Н. А. Рыжков, Т. В. Гаврилова, А. Г. Максимов, Т. Г. Максимова; под ред. В. В. Уйба. - СПб.: Наука, 2009. - 140 с.

10. Мировая статистика здравоохранения 2009. - ВО3, 2009. - 150 c. - http://www.who.int/entity/whosis/whostat/ RU_WHS09_Full.pdf.

11. Национальный доклад Российской Федерации о ходе выполнения Декларации о приверженности делу борьбы с ВИЧ/СПИДом, принятой в ходе 26-й специальной сессии Генеральной Ассамблеи ООН, июнь 2001 г. Отчетный период: январь 2008 года - декабрь 2009 года. М.: Министерство здравоохранения и социального развития Российской Федерации, Федеральная служба по надзору в сфере защиты прав потребителей и благополучия человека. 2010.100 с.

12. Основные показатели деятельности Министерства здравоохранения и социального развития Российской Федерации как субъекта бюджетного планирования на 2008 год и на период до 2010 года: Приложение № 1 к Докладу о результатах и основных направлениях деятельности Минздравсоцразвития России на 2008 год и на период до 2010 года. [Электронный ресурc]. URL: http://www.minzdravsoc.ru/ministry/budget

13. Подпрограмма «ВИЧ-инфекция» (с изменениями от 18 февраля, 2 июня 2008 г., 9 апреля 2009 г.6 апреля, 28 декабря 2011 г.). [Электронный ресурc]. URL: http://base.garant.ru/4184672/\#13000. 
14. Покровский В.В. Современная ситуация по ВИЧ-инфекции в Российской Федерации // Материалы выступления на слушаньях в Общественной палате Российской Федерации 30 марта 2012 г. [Электронный pecypc]. URL: http://www. oprf.ru/files/dok2012/pokrovskiy30032012.pps.

15. Приложение № 3 к федеральной целевой программе «Предупреждение и борьба с социально значимыми заболеваниями (2007-2012 годы)» (в редакции постановления Правительства РФ от 28 декабря 2011 г. № 1167. [Электронный pecypc]. URL: http://base.garant.ru/4184672/\#30000.

16. Проблемы и направления комплексной оценки эпидемии ВИЧ/СПИД в Российской Федерации / Черешнев В. А., Верзилин Д. Н., Гаврилова Т. В., Максимов А. Г., Максимова Т. Г., Черешнева М. В. // Вестник уральской медицинской академической науки. - 2011. - № 2. - С. 19-23.

17. Распределение средств субъекта бюджетного планирования по целям, задачам и бюджетным целевым программам: Приложение № 5 к Докладу о результатах и основных направлениях деятельности Минздравсоцразвития России на 2008 год и на период до 2010 года. [Электронный ресурc]. URL: http://www.minzdravsoc.ru/ministry/budget.

18. Рекомендации слушаний Общественной палаты Российской Федерации «Профилактика ВИЧ-инфекции в России. Проблемы и перспективы». М., 2011. [Электронный ресурс]. URL: http://duma.hivpolicy.ru/assets/files/Recommendations_ OPRF.pdf.

19. Сведения о параметрах реализации приоритетного национального проекта «Здоровье». Министерство здравоохранения и социального развития Российской Федерации на 1 января 2010 г., 1 января 2012 г. [Электронный pecypc]. URL: http://www.minzdravsoc.ru/docs/mzsr/spa/40/PF_Zdorovye_2009_God_15_02_2010xls

20. Сведения о параметрах реализации приоритетного национального проекта «Здоровье». Министерство здравоохранения и социального развития Российской Федерации на 1 января 2012 г. [Электронный pecypc]. URL: http://www. minzdravsoc.ru/docs/mzsr/spa/40/PF_Zdorovye_2011__God_MZSR_06.03.2012.xls.

21. Справка. ВИЧ-инфекция в Российской Федерации в 2011 г. Федеральный научно-методический Центр по профилактике и борьбе со СПИДом, 2011. [Электронный ресурc]. URL: http://www.hivrussia.ru/stat/2011.shtml

22. Стратегия национальной безопасности Российской Федерации до 2020 года. Утверждена Указом Президента Российской Федерации от 12 мая 2009 г. № 537. [Электронный ресурc]. URL: http://www.scrf.gov.ru/documents/1/99.html.

23. Уйба В. В., Максимов А. Г., Максимов Г. К. Методология оценки движения больных с хроническими заболеваниями по данным диспансерного наблюдения // Вестник Военно-медицинской академии. Приложение. - 2007. - №4(20). — С. 91.

24. Уйба В.В., Максимов Г.К., Максимов А.Г. Модели заболеваемости в планировании ресурсов здравоохранения // Вестник Военно-медицинской академии. - 2008. - №4.

25. Хоппенбауэр Дж., Сергеев Б., Ницше-Белл А. Анализ системы мониторинга и оценки по проблема ВИЧ-инфекции и СПИДа в Российской Федерации. - Москва: ЮНЕЙДС, 2005. - 96 с. [Электронный pecypc]. URL: http://www.unaids.ru/ files/documents/ru338.pdf.

26. Черешнев В. А., Максимов А.Г. О доказательной оценке естественного движения хронических больных по данным о динамике показателей заболеваемости населения. На примере злокачественных новообразований // Пермский медицинский журнал. - 2004. - №2. - С. 4-7.

27. Getting to zero: 2011-2015 strategy Joint United Nations Programme on HIV/AIDS (UNAIDS). [Electronic resource]. URL: http://www.unaids.org/

28. Global report: UNAIDS report on the global AIDS epidemic. Joint United Nations Programme on HIV/AIDS (UNAIDS) 2010. 364 p. [Electronic resource]. URL: http://www.unaids.org/globalreport/Global_report.htm

29. How to get to zero. Faster. Smarter. Better. Joint United Nations Programme on HIV/AIDS (UNAIDS). - 2001. 52 p. [Electronic resource]. URL: http://www.unaids.org/en/media/unaids/contentassets/documents/unaidspublication/2011/JC2216_ WorldAIDSday_report_2011_en.pdf.

30. World health statistics 2009. WHO, 2009. 150 p. [Electronic resource]. URL: http://www.who.int/entity/whosis/whostat/ EN_WHS09_Full.pdf.

\section{Информация об авторах}

Черешнев Валерий Александрович (Екатеринбург) - доктор медицинских наук, профессор, академик РАН и РАМН, Институт иммунологии и физиологии Уральского отделения РАН (620049, г. Екатеринбург ул. Первомайская, 106, е-таil: v.chereshnev@iip.uran.ru)

Верзилин Дмитрий Николаевич (Санкт-Петербург) - доктор экономических наук, профессор, Санкт-Петербургский институт информатики и автоматизации РАН (199178, Россия, г. Санкт-Петербург, 14 линия, 39, e-mail: modusponens@ mail.ru)

Максимова Татьяна Геннадьевна (Санкт-Петербург) - доктор экономических наук, профессор, Санкт-Петербургский торгово-экономический институт (194021, г. Санкт-Петербург, ул. Новороссийская, 50, e-mail: maximovatg@gmail.com)

Черешнева Елена Валерьевна (Санкт-Петербург) - аспирант Санкт-Петербургский торгово-экономический институт (194021, г. Санкт-Петербург, ул. Новороссийская, 50, e-mail: maximovatg@gmail.com).

\section{A. Chereshnev, D. N. Verzilin, T. G. Maximova, E. V. Chereshneva}

\section{Socio-economic monitoring of HIV/AIDS threat in the Russian Federation}

The subject of the investigation is social and economic aspects of the threat of HIV / AIDS in the Russian Federation. The investigation was aimed at improving socio-economic monitoring of the HIV / AIDS threat. The methodology of systemic analysis and statistical 
methods were used. Three main sections of socio-economic monitoring of HIV / AIDS were defined with their problems, challenges and areas for improvement. Results of the study are applicable in justifying and shaping public policy to counter the threat of HIV / AIDS. Planned costs of measures to counter the threat of HIV / AIDS must be based on requirements, allocation and results achieved. Systemic approach to planning requires an analysis of interrelation between costs, requirements and results. The absence of a systemic approach to coordination of costs and requirements leads to inefficient use of resources.

Keywords: public policy, morbidity, disease prevalence, socio-economic monitoring, HIV/AIDSthreat.

\section{References}

1. Pokrovskiy V. V., Ladnaya N. N., Buravtsova E. V. (2010). VICh-infektsiya. Informatsionnyy byulleten' № 34 [HIV-infection. Informational bulletin № 34]. Moscow. Available at: http://www.hivrussia.ru/files/bul_34.pdf.

2. Pokrovskiy V. V., Ladnaya N. N., Buravtsova E. V., Sokolova E. V. (2011). VICh-infektsiya. Informatsionnyy byulleten’ № 35 [HIV-infection. Informational bulletin № 35]. Moscow. Available at: http://www.hivrussia.ru/files/bul_35.pdf.

3. Dinamika tselevykh indikatorov i pokazateley federal'noy tselevoy programmy «Preduprezhdenie i bor'ba s sotsial'no znachimymi zabolevaniyami (2007-2012 gody)» (s izmeneniyami ot s izmeneniyami ot 18 fevralya 2008 g., 9 aprelya 2009 g., 6 aprelya, 28 dekabrya 2011 g.): Prilozhenie № 1 k federal’noy tselevoy programme «Preduprezhdenie i bor’ba s sotsial'no-znachimymi zabolevaniyami (2007-2012 gody)» [Dynamics of target indicators and indices of the federal target program «Prevention and control of socially significant diseases (2007-2012)» (as amended by the changes from February 18, 2008, April 9, 2009, April 6, 2011 and December 28, 2011): Appendix № 1 to the federal target program «Prevention and control of socially significant diseases (20072012)»]. Available at: http://base.garant.ru/4184672/\#10000.

4. Zabolevaemost' naseleniya sotsial'no znachimymi boleznyami (dannye Minzdravsotsrazvitiya Rossii, raschet Rosstata) [Morbidity of the population with socially significant diseases (data by Health Ministry of Russia, calculations of Federal State Statistics Service)] (2012). Moscow, Federal State Statistics Service, 2012. Available at: http://www.gks.ru/free_doc/new_site/population/zdrav/zdr2-2.xls.

5. Zdravookhranenie v Rossii. 2009 : ctat. sb. [Public health services in Russia. 2009. Statistical digest] (2009). Moscow, Federal State Statistics Service.

6. Instruktivnye dokumenty po primeneniyu instrumentov dlya otsenki i prognozirovaniya [Briefing papers on the application of tools for assessment and prediction]. Project (2009).UNAIDS.

7. Kak priyti k tseli «nol'». Bystree.Razumnee.Luchshe.Doklad YuNEYDS k vsemirnomu dnyu bor'by so SPIDom, 2011 [How to reach the goal of «zero».Faster.Wiser. Better. UNAIDS report for World AIDS Day, 2011]. Available at: http://www.unaids.ru/ sites/default/files/doklad_yuneyds_k_vsemirnomu_dnyu_borby_so_spidom._2011.pdf.

8. Kratkaya kharakteristika deystvuyushchey i (ili) planiruemoy byudzhetnoy tselevoy programmy, v chasti, kasayushcheysya otchetnogo perioda: FTsP «Preduprezhdenie i bor’ba s sotsial’no znachimymi zabolevaniyami (2007-2011 gody)»: Prilozhenie № 4 k Dokladu o rezul'tatakh i osnovnykh napravleniyakh deyatel'nosti Minzdravsotsrazvitiya Rossii na 2008 god i na period do 2010 goda [Brief description of current and (or) a proposed budget targeted program, in respect of the reporting period: Federal Target Program «Prevention and control of socially significant diseases (2007-2011)»: The appendix number 4 to the report on the results and main activities of the Health Ministry of Russia 2008 and until 2010]. Available at: http://www.minzdravsoc.ru/ministry/ budget.

9. Uyba V.V., Maksimov G.K., Ryzhkov N.A., Gavrilova T.V., Maksimov A.G., Maksimova T.G. (2009). Metodologiya otsenivaniya i analiza obshchestvennogo zdorov'ya [Methodology of estimation and analysis of public health]. Saint Petersburg, Nauka.

10. Mirovaya statistika zdravookhraneniya 2009 [World statistics of public health care services] (2009). World Health Organization. Available at: http://www.who.int/entity/whosis/whostat/RU_WHS09_Full.pdf.

11. Natsional'nyy doklad Rossiyskoy Federatsii o khode vypolneniya Deklaratsii o priverzhennosti delu bor'by s VICh/SPIDom, prinyatoy v khode 26-y spetsial'noy sessii General'noy Assamblei OON, iyun' 2001 g. Otchetnyy period: yanvar' 2008 goda dekabr' 2009 goda [National Report of the Russian Federation on the Implementation of the Declaration of Commitment on HIV / AIDS, adopted at the 26th special session of the UN General Assembly in June 2001. Reporting period: January 2008 - December 2009] (2010).Moscow, Ministry of Health Care and Social Development of the Russian Federation, Russian Federal Consumer Rights Protection and Human Health Control Service.

12. Osnovnye pokazateli deyatel'nosti Ministerstva zdravookhraneniya i sotsial'nogo razvitiya Rossiyskoy Federatsii kak subekta byudzhetnogo planirovaniya na 2008 god i na period do 2010 goda: Prilozhenie № 1 k Dokladu o rezul'tatakh i osnovnykh napravleniyakh deyatel'nosti Minzdravsotsrazvitiya Rossii na 2008 god i na period do 2010 goda [Key figures of the Ministry of Health Care and Social Development of the Russian Federation as the subject of budget planning for 2008 and the period up to 2010: Appendix № 1 to the Report on the results and main activities of the Ministry of Health Care and Social Development of the Russian Federation Ru in 2008 and until 2010]. Available at: http://www.minzdravsoc.ru/ministry/budget

13. Podprogramma «VICh-infektsiya» (s izmeneniyami ot 18 fevralya, 2 iyunya 2008 g., 9 aprelya 2009 g., 6 aprelya, 28 dekabrya 2011 g.) [Sub-program «HIV infection» (as amended on February, 18, 2008, June 2, 2008, April 9, 2009, April 6, 2011, December 28, 2011)]. Available at: http://base.garant.ru/4184672/\#13000.

14. Pokrovskiy V. V. (2012). Sovremennaya situatsiya po VICh-infektsii v Rossiyskoy Federatsii [The current situation on HIV infection in the Russian Federation]. Materialy vystupleniya na slushan'yakh v Obshchestvennoy palate Rossiyskoy Federatsii 30 marta 2012 g. [Proceedings of hearings at the Public Chamber of the Russian Federation on March 30, 2012]. Available at: http:// www.oprf.ru/files/dok2012/pokrovskiy30032012.pps.

15. Prilozhenie №3 k federal’noy tselevoy programme «Preduprezhdenie i bor’ba s sotsial’no znachimymi zabolevaniyami (2007-2012 gody)» (v redaktsii postanovleniya Pravitel’stva RF ot 28 dekabrya 2011 g. № 1167 [Appendix № 3 of the Federal Target 
Program «Prevention and control of socially significant diseases (2007-2012)» (in the wording of the Government of the Russian Federation Decree of 28 December 2011 № 1167]. Available at: http://base.garant.ru/4184672/\#30000.

16. Chereshnev V.A., Verzilin D. N., Gavrilova T. V., Maksimov A. G., Maksimova T. G., Chereshneva M. V. (2011). Problemy i napravleniya kompleksnoy otsenki epidemii VICh/SPID v Rossiyskoy Federatsii [Problems and directions of integrated assessment of the HIV / AIDS epidemy in the Russian Federation].Vestnik ural'skoy meditsinskoy akademicheskoy nauki [Bulletin of the Ural academic medical science], 2, 19-23.

17. Raspredelenie sredstv sub'ekta byudzhetnogo planirovaniya po tselyam, zadacham i byudzhetnym tselevym programmam: Prilozhenie № 5 k Dokladu o rezul’tatakh i osnovnykh napravleniyakh deyatel’nosti Minzdravsotsrazvitiya Rossii na 2008 god i na period do 2010 goda [Allocation of budgetary funds subject to budgetary planning goals, objectives and budget target programs: Appendix number 5 of the Report on the results and main activities of the Ministry of Health Care and Social Development of the Russian Federation for 2008 and the period up to 2010]. Available at: http://www.minzdravsoc.ru/ministry/budget.

18. Rekomendatsii slushaniy Obshchestvennoy palaty Rossiyskoy Federatsii «Profilaktika VICh-infektsii v Rossii. Problemy i perspektivy» [of hearings at the Public Chamber of the Russian Federation «Preventive measures on HIV infection in the Russian Federation.Problems and perspectives»] (2011). Moscow. Available at: http://duma.hivpolicy.ru/assets/files/Recommendations_ OPRF.pdf.

19. Svedeniya o parametrakh realizatsii prioritetnogo natsional'nogo proekta «Zdorov’e. Ministerstvo zdravookhraneniya i sotsial'nogo razvitiya Rossiyskoy Federatsii na 1 yanvarya 2010 g., 1 yanvarya 2012 g. [Information on the implementation of priority national project «Health». Ministry of Health Care and Social Development of the Russian Federation, as on January, 1, 2010]. Available at: http://www.minzdravsoc.ru/docs/mzsr/spa/40/PF_Zdorovye_2009_God_15_02_2010xls

20. Svedeniya o parametrakh realizatsii prioritetnogo natsional'nogo proekta «Zdorov’e». Ministerstvo zdravookhraneniya i sotsial'nogo razvitiya Rossiyskoy Federatsii na 1 yanvarya 2012 g. [Information on the implementation of priority national project «Health». Ministry of Health Care and Social Development of the Russian Federation, as on January, 1, 2012]. Available at: http:// www.minzdravsoc.ru/docs/mzsr/spa/40/PF_Zdorovye_2011_God_MZSR_06.03.2012.xls.

21. Spravka. VICh-infektsiya v Rossiyskoy Federatsii v 2011 g. [[Reference guide.HIV infection in the Russian Federation in 2011].Federal'nyy nauchno-metodicheskiy Tsentr po profilaktike i bor'be so SPIDom [Federal Research and Methodological Center for Prevention and Control of AIDS, 2011]. Available at: http://www.hivrussia.ru/stat/2011.shtml

22. Strategiya natsional'noy bezopasnosti Rossiyskoy Federatsii do 2020 goda. Utverzhdena Ukazom Prezidenta Rossiyskoy Federatsii ot 12 maya 2009 g. № 537 [The National Security Strategy of the Russian Federation until 2020. Approved by the Decree of the President of the Russian Federation on May 12, 2009 № 537]. Available at: http://www.scrf.gov.ru/documents/1/99.html.

23. Uyba V. V., Maksimov A. G., Maksimov G. K. (2007). Metodologiya otsenki dvizheniya bol'nykh s khronicheskimi zabolevaniyami po dannym dispansernogo nablyudeniya [Methodology for assessing the movement of patients with chronic diseases according to dispensary observation].Vestnik Voenno-meditsinskoy akademii [Bulletin of Military-Medical Academy].Appendix, $4(20), 91$.

24. Uyba V.V., Maksimov G. K., Maksimov A. G. (2008). Modeli zabolevaemosti v planirovanii resursov zdravookhraneniya [Models of morbidity, incidence of a disease in planning the resources of public health care services]. Vestnik Voenno-meditsinskoy akademii [Bulletin of Military-Medical Academy]. — 2008. — № 4.

25. Khoppenbauer Dzh., Sergeev B., Nitsshe-Bell A. (2005). Analiz sistemy monitoringa i otsenki po problema VICh-infektsii i SPIDa v Rossiyskoy Federatsii [Analysis of monitoring and evaluation system for HIV infection and AIDS problems in the Russian Federation]. Moscow, UNAIDS. Available at: http://www.unaids.ru/files/documents/ru338.pdf.

26. Chereshnev V.A., Maksimov A. G. (2004). O dokazatel'noy otsenke estestvennogo dvizheniya khronicheskikh bol'nykh po dannym o dinamike pokazateley zabolevaemosti naseleniya. Na primere zlokachestvennykh novoobrazovaniy [On the evidencebased evaluation of natural movement of patients with chronic diseases on the data of the dynamics of the morbidity of the population.On the example of malignant neoplasms].Permskiy meditsinskiy zhurnal [Perm Medical Journal], 2, 4-7.

27. Getting to zero: 2011-2015 strategy Joint United Nations Programme on HIV/AIDS (UNAIDS). Available at: http://www. unaids.org/

28. Global report: UNAIDS report on the global AIDS epidemic. Joint United Nations Programme on HIV/AIDS (UNAIDS) 2010. Available at: http://www.unaids.org/globalreport/Global_report.htm

29. How to get to zero.Faster.Smarter. Better. Joint United Nations Programme on HIV/AIDS (UNAIDS) (2001). Available at: http://www.unaids.org/en/media/unaids/contentassets/documents/unaidspublication/2011/JC2216_WorldAIDSday_report_2011_en.pdf.

30. World health statistics 2009. WHO. Available at: http://www.who.int/entity/whosis/whostat/EN_WHS09_Full.pdf.

\section{Information about the authors}

Chereshnev Valeriy Aleksandrovich (Yekaterinburg, Russia) - Doctor of Medical Science, Professor, member of the Russian Academy of Sciencesand Russian Academy of Medical Sciences, Institute of Immunology and Physiology, Ural Branch of Russian Academy of Sciences (620049, Yekaterinburg,Pervomaiskaya st., 106, e-mail: v.chereshnev@iip.uran.ru).

Verzilin Dmitriy Nikolaevich (Saint Petersburg, Russia) - Doctor of Medical Science, Professor, Saint Petersburg Institute of Informatics and Automation, Russian Academy of Sciences (199178, Saint Petersburg, 14 liniya, 39, e-mail: modusponens@mail. $\mathrm{ru})$.

Maksimova Tat'yana Gennad'evna (Saint Petersburg, Russia) - Doctor of Economics, Professor, Saint Petersburg Institute of Trade and Economics (194021, Saint Petersburg, Novorossijskaya st., 50, e-mail: maximovatg@gmail.com).

Chereshneva Elena Valer'evna (Saint Petersburg, Russia) — PhD student at Saint Petersburg Institute of Trade and Economics (194021, Saint Petersburg, Novorossijskaya st., 50, e-mail: maximovatg@gmail.com). 